\title{
I's Wide Shut: Examining the Depiction of Female Refugees' Eyes and Hands in Stephen Frears's Dirty Pretty Things
}

\author{
JENNY WILLS
}

\section{Abstract}

In 2002, Stephen Frears directed Dirty Pretty Things one of the few mainstream fictional films to highlight the effects of exile, the complexities of refugee status, and the trials of migrant labour in the "Western" world. Thus far, the minimal number of "refugee" films produced is mirrored by the minimal discussion about those films (or their absence). This essay examines Frears's film with a critical lens that incorporates both theoretical evaluations and aesthetic choices. For instance: how do media representations of refugees and migrants relegate the signification of refugee-ism to visceral, silent, repetitiv,e and subordinated signifiers? Additionally, this essay narrows its interest upon Senay, the female lead of Dirty Pretty Things, to open up a dialogue about fragmented body: missing hands / hyperbolized eyes. Drawing on knowledge of the theoretical implications of those choices, this paper addresses refugees and illegal migrants in film with the hope of initiating conversation about an otherwise relatively silent and untouched cinematic subgenre.

\section{Résumé}

En 2002, Stephen Frears réalisa Dirty Pretty Things un des rares films de fiction grand public à mettre en exergue les contrecoups de l'exil, les complexités liées au statut de réfugié et les tribulations du travailleur immigré dans le monde "occidental". Jusqu'ici, le nombre infime de films réalisés sur le thème des "réfugiés" est reflété par le peu de débats sur ces films (ou sur leur absence). Cet essai examine le film de Frears avec un oeil critique qui intègre aussi bien des évaluations théoriques que des considérations esthétiques. Par exemple : comment les représentations des réfugiés et des immigrants dans les médias relèguent-elles le sens du statut de réfugié à des signifiants viscéraux, muets, répétitifs et subordonnés? De plus, cet essai porte un intérêt particulier à Senay, l'actrice principale de Dirty Pretty Things, dans le but de lancer un débat sur la fragmentation du corps: les mains absentes/l'hyperbolique des yeux. S'appuyant sur la connaissance des significations théoriques de ces choix, cet article traite du thème des réfugiés et des migrants illégaux dans les films, dans l'espoir de déclencher un débat sur un sous-genre cinématographique relativement confiné au silence et très peu abordé.

Doctor]: How come I've never seen you people before?

Okwe]: Because we are the people you do not see. We are the ones who drive your cabs. We clean your rooms. And suck your cocks. - Dirty Pretty Things ${ }^{1}$

I $\mathrm{n}$ one of the most anxiety-filled moments of the film Dirty Pretty Things, Stephen Frears's primary character, Okwe, speaks out against the organized dehumanization of refugees ${ }^{2}$ and migrants while he participates in the very trafficking that constructs this version of the London "underground.” Dirty Pretty Things (2002), nominated for numerous industry awards, including an Oscar in the category of "Best Writing" for screenwriter Stephen Knight, ${ }^{3}$ is one of few contemporary, non-documentary, mainstream feature films that addresses the after-effects of illegal immigration and the continuousness of refugee and migrant exploitation in the $\mathrm{West}^{4}$ as its primary narrative plot. ${ }^{5}$ With a filmography of relatively few works, refugee narratives lack 
the volume necessary to qualify as an obvious cinematic genre, and therefore are struggling to make the political impact that thinkers like Michael M. J. Fischer argue they are capable of. ${ }^{6}$ Furthermore, and as a result, there is an absence of critical theory surrounding the limited number of films that exist that fittingly parallels the silence of the subjects themselves. Even Terrence Wright, one of the few theorists who have published on the topic of refugees and motion pictures, inadvertently draws attention to the lack of unique criticism granted to refugee and migrant fiction film. Situating refugee films within broader generic groups that homogenize the experiences of refugees and archetype the works in a manner that could potentially be disempowering, Wright is forced to look outside of the limited selection of filmic examples to determine generic qualities with which to connect the texts. Describing the goal of his introductory essay entitled "Refugees on Screen," Wright announces that his work "considers the ways that the refugee story has been structured in fiction film and proposes that feature film portrayals can conform to the "road movie" film genre." acknowledging refugee and migrant ${ }^{8}$ labourer fiction film within the qualifying characteristics of another genre, Wright points to the lack of individualism, subjectivity, and voice of cinema featuring refugee narratives.

Allen Feldman takes a more visceral approach to examining representations of refugees and illegal migrants on screen:

Generalities of bodies - dead, wounded, starving, diseased, and homeless - are pressed against the television screen as mass articles. In their pervasive depersonalization, this anonymous corporeality functions as an allegory of the elephantine, 'archaic,' and violent histories of external and internal subalterns. ${ }^{9}$

What is clear from Allen Feldman's observations is that the refugee is overtly visualized in the media, reduced to her body in a visceral, sensationalized, and grotesque manner that is best described as Julia Kristeva's "abject." 10 Emphasizing the corporeality of media representations of the refugee and migrant labourer (in this case, in non-fiction) therefore illustrates the simultaneously trivialized and essentialized underminings of the political or psychological profundity of the migrant state - relegating her signification to the visual suffering of her isolated body. Prem Kuma Rajaram notes that "the refugee is lost. [...] Without citizenship her plight is not to be characterized as merely culturally or physically precarious, she is without help, without the means to call on the protective agency as state," 11 drawing attention to the refugee's political lack, while highlighting the necessity to evaluate refugee status beyond her physical experience. Thus, characters like Okwe, who identify with the refugee's desire for asylum, but who are politically invisible, are emblematic of the invisibility of refugees beyond their alien bodies. Yet further in his article, Rajaram poignantly recognizes that "refugees are consigned to their bod[ies]"12 - an acknowledgement that suggests the futility of challenging media representations of illegal migrant bodies. Rather than disavowing the physical depiction of refugees and migrant bodies on screen, it instead becomes a crucial task to evaluate and deconstruct the mythological meanings behind these representations - highlighting the generated implications of those cinematic choices. Thus, this article will evaluate the visualized representation of the female migrant body as it appears in Frears's Dirty Pretty Things, examining how cinematography perpetuates the fragmentation and corporeality of the illegal alien body and the latent inferences of those methods. For within Frears's narrative, the female migrant body is depicted not only by excessive focus on Senay's eyes but also by the absent representation of her hands through framing and camera angle. Alluding to specific qualities of migrant and refugee status, including melancholia, silence, mechanization, and liminality, this article will illustrate how the filmic depiction of Senay's eyes and hands metaphorically highlight the social, psychological, and political characteristics of her exile. ${ }^{13}$

Set within the paradoxical sceneries of panicked sweatshops and classy hotels, Frears's film highlights the sordid world of migrant labour in London. Okwe, a former Nigerian doctor, and Senay, his Turkish co-worker and friend, struggle to survive while deceiving the immigration department, by working as a hotel receptionist/taxi driver/unlicensed surgeon and chambermaid/sweatshop worker respectively. Both Okwe and Senay are dehumanized by the employment options available to them - options that are interestingly similar, despite their dissimilar alien statuses. Following their troubled relationship, Dirty Pretty Things takes a surprising turn when Okwe discovers that his employer, Señor "Sneaky" Juan, traffics not only drugs and sex, but human organs as well. With the promise of citizenship, passports, and security (promises that appeal to Okwe as an illegal migrant despite his need for refugee status, and to Senay as a legal migrant, but who finds herself even more restricted and monitored than her friend), Juan encourages illegal migrants to "donate" their organs to his black-market industry, blackmailing Okwe to put his former medical expertise to work as a surgeon. Okwe consults his friend Guo Yi, a mortician at the hospital, for advice and support, but ultimately complies with Juan's demands. Senay, on the other hand, finds herself easily dispensable in a sweatshop after immigration officers target her for deportation. Two burly men search her apartment and follow her around London, fixated on the task of uncovering the truth about 
Senay - that she has indeed been working regardless of her non-citizen status. Forcing their way into her apartment and searching her belongings, and later, almost catching her coming to work at the hotel where she works with Okwe and Juan, the immigration officers follow Senay to her new job at a garment factory. Her employer, aware of her precarious position, repeatedly rapes her with forced fellatio, relegating her formerly industrialized corporeality to one of sexual subordination as well. After repeatedly submitting to her boss's demands, Senay eventually breaks free. In an interesting parallel, Senay must seek refuge from the sweatshop - and eventually does so by fleeing the country. Unfortunately, before she is able to 'escape' into the United States, she is lured by Señor Juan into both sleeping with him and selling her organs on his black market. ${ }^{14}$ Objectified by both the dehumanizing nature of her employment and various forms of inflicted sexual assault, Senay is uncomfortably silent and passive, until the conclusion of the film when she is able to assist in the reclamation of empowerment - taking back what was stolen from her and other trapped migrants: ownership of her own body.

\section{Psychoanlaysis and Cinema: Translating the Refugee's Body on Screen}

When Sigmund Freud differentiates the concept of mourning from melancholia, he contends that both states are triggered by a "reaction to the loss of a loved person, or to the loss of some abstraction which has taken the place of one, such as one's country, liberty, and ideal, and so on." ${ }^{15} \mathrm{He}$ goes on to note that the act of mourning progresses by means of a successful experience of grief, relinquishing emotional ties to the lost concept. ${ }^{16}$ Melancholics, conversely, are unable to rid themselves of their loss, instead absorbing the loss into themselves. Two things are highlighted by Freud's statements. First, the elements included in the above citation ("country, liberty, and ideal") make an interesting allusion to the exiled individual, or at least to migrant experience or Diasporic subjectivity. For refugees and migrants are not uncommonly noted as troubled by their lack of nationality, citizenry, political and financial freedom, and ethnic ideology. Freud's emphasis on the above-listed constituents of "loss" suggests his awareness of the inherent and unavoidable melancholia of refugees, exiles, and migrants. Second, Freud claims that melancholics are incapable of successful mourning - and, thus, cannot remove themselves from their grief-stricken state. However, melancholy is a component of mourning - a melancholic disorder forming whence the griever is unable to progress from a melancholic state into one of natural mourning and, eventually, to relief. I contend that the numerous narcissistic objects contributing to the migrant's ego that are lost (home, family, nationality, cul- ture, history, etc.) result in an inability to accurately recognize the specific amalgamation of objects of loss - thereby disabling proper mourning and resulting in perpetual melancholia. In other words, the assortment of the migrant's losses - citizenship, ethnicity, security, subjectivity, and liberty (to name a few) - produce so disarrayed a source of anxiety that none are properly overcome (i.e. mourning is unachieved), and, thus, the migrant suffers melancholic despair. Add to this circumstance the impossibility of ever regaining that stability of that previous national identification, or at the very least, the nostalgic comfort of one's country (or culture) of origin, and it becomes clear that the refugee state is one of melancholic unbalance.

Edward Said likewise incorporates Freud's notions of mourning and melancholia when he writes his numerous texts concerning exile. ${ }^{17}$ Said contends that the exile's present behaviour is linked directly to her loss of the past. In the essay "Reflections on Exile," he notes that being an exile implies that one is in a "fundamentally [...] discontinuous state of being. Exiles [including refugees] are cut off from their roots, their land, their past." 18 This severance results in psychological sorrow and what Bruce Robbins refers to as "dizzying unanchoredness." 19 Robbins goes on to elaborate on the melancholic effects outlined in Said's work, asserting, "Said is our foremost specialist in polymorphous disorder [...] the chronic ache of exile from origin, tradition, and home culture that enervates modern critical consciousness." ${ }^{20}$ Emphasized in Robbins's statement is the non-linear web of lost (abstract) objects that the refugee lacks - reiterating the melancholic disarray of anxiety previously outlined in this article. Polymorphous disorder, or "assuming [...] various forms; multiform" 21 suggests a connection between Said's theory and melancholia (as opposed to mourning) both by its allusion to numerous objects of loss and by its classification as a disorder (Freud claims that mourning is natural but that melancholia is $\left.\operatorname{not}^{22}\right)$.

I wish to impose a brief literary examination to link the act of looking and eyes to the representation of mourning (as the encompassing term that includes melancholia) before returning to the filmic representation of the female migrant's body in relation to Freud's and Said's analyses. First, Freud's description of E. T. A. Hoffmann's narrative "The Sand-Man" alludes to "the fear of damaging or losing one's eyes." 23 The psychoanalyst later reveals that the anxiety related to potential blindness is synonymous in degree only with the anxiety of castration - implicitly equating the eyes with the phallus - the egotistical narcissistic object. ${ }^{24}$ The narcissistic object, in turn, gains importance, as it is through ego development that natural mourning is overcome. Furthermore, the trope relating eyes to mourning is 
popular in both narrative and visual genres. Consider Shakespeare's likening of eyes to literal in Sonnet 132 ("Thine eyes I love [...] / Have put on black, and loving mourners be $[\ldots]$ " and "As those two mourning eyes become thy face" $)^{25}$ or the tragic eyes of the saints and followers in Raphael's The Entombment. ${ }^{26}$ Many artists have notoriously located mourning and melancholia within their subjects' eyes, not only as the sites of purgation through tears, but also as signifiers that emblemize sorrow and pathos. Consider the affective portrayal of emotion through eyes in Munch's The Scream for an obvious example of how pain and passion are hauntingly expressed through the character's eyes.

Perhaps the basis of the link lies within the noiseless yet unsilenced manner that expression is revealed through a mourner's eyes, enabling profound articulation of pain that is beyond any vocalization of the like. In Dirty Pretty Things, it is through her eyes that Senay expresses the depth of her sadness. As the camera frequently moves into close-up on Senay, it is her haunting eyes that capture the viewer's attention - eyes that are large with both naïveté and experience. For instance, Senay's face is framed between the clothing racks, her anxious eyes peering over the metal bars while the rest of her face remains hidden from the screen. The audience reads from her expression the profundity of her terror - both of immigration officials and of the exploiters of her limited status in England (i.e. her boss who forces her to perform fellatio upon him, threatening that he will otherwise report her to the government). Even from the first appearance of Senay - as she turns her face upward into the surveillance camera's view - her eyes are mysterious and sad, expressing the dehumanizing mechanization of her employment, a component of her refugee status. It is in her eyes that Senay demonstrates the melancholy of exile described by Freud and Said - eyes that are large with grief, dark with anxiety, and open with expression.

In response to Spivak's famously asked question, "Can the Subaltern Speak?"27 Frears acknowledges varying methods of communication that, although not as effective as voice in immediate force, are subtly haunting and express more than words ever could. For it is with her eyes that Senay speaks her emotions. Her unblinking gaze at Okwe makes apparent her love for him, but also illustrates that she simultaneously fears that love and its repercussions. Her fixed stare sizes up Señor Juan when she agrees to undergo surgery, illustrating both the terror and desperation that have led her to this decision. Senay's unsilenced eyes express the emotions that her speechless voice is unable to, whether out of propriety or dread. When Barber Ali's character first forces himself onto Senay amongst the racks of clothing, he holds her mouth shut while uttering his request. Her jaw restrained, it is only in Senay's unforgettable eyes that the viewer understands her profound grief. She cries to Okwe on the telephone afterward, yet her voice is incoherent and uncommunicative, as Okwe struggles to find meaning in her words. However, there is no miscommunication between them when he finds her in the office of the taxi company he works for. Shortly after Senay has refused to be victimized by her sweatshop boss, she waits silently for Okwe in the backroom. Upon looking into the darkness of her eyes, he is aware that something horrendous has occurred.

And it is not surprising that the female migrant's voice is constricted in Dirty Pretty Things, and is thus projected onto other body parts. For, as Prem Kumar Rajaram would suggest, speechlessness is a universalizing characteristic common in all refugee experiences. In an article entitled "Humanitarianism and Representations of the Refugee," Rajaram contends that the refugee's political and social abandonment leaves her with only "biological corporeality," 28 negating any voice of assertion of empowerment ${ }^{29}$. Rajaram writes:

The connection of political identity and discourse to the territorial state means that those without citizenship or bereft of it are speechless (or taken to be speechless), requiring an agency or expert to speak for them. The 'speechlessness' of refugees reinforces the state-centric political imagination. ${ }^{30}$

Implicit in Rajaram's passage is the relationship between the refugee's lack (nationality, political support, financial and familial provision) that contributes to her voicelessness. Similar circumstances factor into Senay's silence in Frears's narrative, as Senay is denied speech due to the restrictions placed on her "legal" migrant status. ${ }^{31}$ She cannot report her boss's wrongdoings, as she will be revealed as working illegally against the terms of her residency. Thus, she remains silent throughout the attacks, unprotected by the police as a result of her marginalized position, with only her eyes to express her devastation at the situation.

Kerry Demusz offers an alternative potentiality for refugee silence. She notes of the conflict zones in Sri Lanka that the "voices of the refugees, the displaced, the mothers and the children who have to live in a world torn apart by conflict or by natural disaster" are restricted by so-called government aid agencies, such as Oxfam. ${ }^{32}$ Demusz contends that it is specific political agendas that silence refugees and disallow them a voice. Rajaram extrapolates Demusz's ideas in his essay. He acknowledges the consequences of politically imposed silence on refugees, stating that "they are rendered speechless and without agency, a physical entity, or rather a physical mass within which individuality 
is subsumed. Corporeal refugees are speechless and consigned to 'visuality': to the pictorial representation of suffering and need." ${ }^{33}$ In a like manner, while Senay's political desperation instigates her silence, her body becomes the visual focal point of her so-called subjectivity.

Unfortunately, Senay's silent body quickly becomes Orientalized by cinematic observers of dominant culture. Embodying many of the qualities characteristic of the Oriental (mystery, exoticism, passivity, and silence), her character risks perpetuating the migrant stereotype in film and media. Rajaram continues his argument by alluding to the refugee's place in the culture industry. He notes that "[o]ne of the central effects of this consignment [of the refugee to her corporeal body] is the 'commodification' of the refugee experience. $[\ldots][R]$ efugee events and experiences become a site where Western ways of knowing may be reproduced and recycled." ${ }^{34}$ Being adopted into the culture industry as the stereotypical Oriental, ${ }^{35}$ Senay's body perpetuates Western ideologies that consistently render the migrant silent by their corporeal visualizations and depictions. These expectations, in turn, eliminate the individuality of the migrant, thereby restricting her subjectivity. For, as Liisa H. Malkki notes in her essay "From 'Refugee Studies' to the Natural Order of Things," media archetypification results in an oversimplification of refugee features. She writes that:

the term refugee has analytical usefulness not as a label for a special, generalizable "kind" or "type" of person or situation, but only as a broad legal or descriptive rubric that includes within it a world of different socio-economic statuses, personal histories, and psychological or spiritual situations. ${ }^{36}$

Malkki's statement suggests the impersonal, overarching potential of a term like "refugee," as it removes individuality from the exile, similar to the processes of cinematic stereotypification. The same could be said for discourses surrounding "exiles," "others," and "migrants." For Senay's silent performance renders her as Oriental, thus fuelling expectations and perpetuating archetypes of being alien that rely on silence and bodily representation.

Rey Chow adopts this notion of bodily objectification through silence in her essay "Postmodern Automatons," which appears in Judith Butler and Joan W. Scott's anthology, Feminists Theorize the Political. She contends that "one of the chief sources of the oppression of women lies in the way they have been consigned to visuality." ${ }^{37}$ This visuality, in turn, results in archetypification and expectation, performances of repetition that are predictable and thus mechanized. Chow suggests that the female body is turned into an "automaton," and citing J. Smith characterizes such as a being that "can be guaranteed to think, speak and act exactly as you would expect." 38 In other words, the visuality of the female body reduces her to mechanical predictability, hyperbolizes stereotypes, and thus commodifies the female body into an industry that perpetuates its ideology using her image as a conduit for mythological dissemination.

Not only does Senay's body in Dirty Pretty Things illustrate this process of archetypification stemming from speechlessness and bodily representation (and, arguably, expressions from the eyes), but her body likewise is transformed into the automaton Chow speaks of through additional means, including economics. The mechanical nature of female migrant labour results in mundane, uncreative, and silent employment patterns whose foundations rely on the worker's repetition of particular movements. When Judith Butler concludes her foundational text, Gender Trouble, she makes the important claim that "the subject is not determined by the rules through which it is generated because signification is not a founding act, but rather a regulated process of repetition." 39 In other words, a subject is not defined through self-decided acts, but instead is recognized within a structure of repeated performances performances that, if unquestioned, construct a socially subordinate object. Butler's theory can be extended to evaluate the repetition of movements performed by Senay as her body is visualized as executing the same actions repeatedly When Senay finds employment at the sweatshop, she replicates her movements in order to mass-produce the proper garments. She is objectified by her work merely from her repetitious, non-agency performances, only gaining subjectivity and freedom from the structure when she subverts the system. Senay's declaration that "today I bit. I bit. I bit" represents her refusal to perpetuate the repetitious cycle of her objectification - finally breaking out of the performance she was forced to embody for so long. For, similar to the Victorian industry of textiles, an industry that Beth Harris claims embodies "the dull, repetitious act of plying the needle represent[ing ...] unfair confinement," ${ }^{40}$ until this subversion, Senay's employment consists of pattern following - unoriginal, uncreative, and tedious. Even sexuality (as it is related to employment) is a repetitive performance, as Senay's repeated forced-fellatio upon her boss is painfully constructed by her expectant reaction to the demand and repeated voiceless compliance of it.

I wish to now shift the focus of this article from the relationship of eyes to mourning and speechlessness (and thus bodily visualization) to the mutually significant depiction of the female migrant labourer's hands. For, further emphasizing the robotic nature of the marginalized female migrant, work is her undeniable relationship to machinery - 
in Dirty Pretty Things, Senay's hands work in accordance with technology. Often observed as the user of factory machinery, female migrants in film are visualized in relation to their technical instruments - whereas male migrants use their own hands and voices to perform their work. Consider Okwe's occupations in Dirty Pretty Things. Aside from his taxi driving position when he obviously has to rely on technology to properly do his job, when he works as an unlicensed doctor or as a hotel concierge, he is frequently pictured as using his hands to directly perform his work. Senay, by comparison, is only seen working as an extension of the sewing machine that she utilizes at the sweat shop. Unlike her boss, who is twice pictured as sewing by hand, or Guo Yi, who hand-sews the pockets shut on his Asian morgue patients, Senay performs the same duty but through the conduit of a machine. Her hands remain unseen.

So often does the cinematic representation of female migrant labourer's work construct the machine as an extension of her own body that her own identity eventually coincides with the mechanical nature of her employment. In her text, "The Female Machine in the Postmodern Circuit," Annemarie Kemeny cites Hanjo Berressem when he says that "the concept of [...] psychic and cultural colonization $[\ldots]$, is a gesture that invades the 'other' and redefines the subject as a pure object[...] result[ing] in a universal streaked through with the mechanical. The female body, however, seems to be the privileged site for this mutation." 41 To clarify, Kemeny suggests that the female body is mechanized in an attempt to maintain the dominant class - by disenfranchising it as the other - the incorporeal. She notes that "the deliberate creation of lack as a function of market economy is the art of a dominant class" - emphasizing the utilitarian motives behind roboticizing female workers to serve economic purposes. ${ }^{42}$

\section{Frears's Cinematic Codification}

Returning to the visualization of migrants and refugees in film, I contend that the disenfranchised nature of the female migrant results in what W. E. B. DuBois would call "double consciousness" 43 - or the act of constantly looking at oneself through the eyes of the dominant culture. The female migrant-turned-refugee in Dirty Pretty Things is thrice"othered" due to her lack of national identity, ethnic resemblance, and phallus. As a result, she becomes emblematic of and ideal for Kemeny's "site of mutation" - or the sacrificial being transformed into the figurative gynoid for the benefit of dominant ideology. In other words, the female migrant is an abject whose signification, due to her politically, economically, and socially vulnerable position, quickly becomes synonymous with machinery - suggesting her unoriginality, archetypification, and lack of subjectivity. Thus, both Senay's haunting silence (and, therefore, corporeal display) and the representation of her body as mechanized perpetuate the myth of the alien (or the "alientalization") prevalent in mainstream cinema.

Yet while Senay's body is positioned so mechanically (in terms of repetitive performance and in relation to machines), there is a striking absentia of filmic framing of her working hands - assumedly the most significant phsyical tool for manual labour. Frears continually alludes to Senay's industrious motions; however, the viewer is offered only a brief glimpse at Senay's working hands as she labours at the sweatshop - but again, her hands work in conjunction with the mechanical sewing machine that she operates. The most common representation of Senay's work pictures her sitting in front of the machine, concentrating downward; motioning with her shoulders to insinuate the nature of her labour - but Frears never allows the camera to actualize these assumptions. This framing choice has the potential to likewise contribute to ideological formation similar to the visualization and mechanization of the female migrant body. For, as John Fiske notes in "Television Culture," "encoding conventions" 44 or "links between producers, texts, and audiences [that] are the agents of intertextuality through which texts interrelate in a network of meanings that constitute our cultural world" 45 eventually "attempt [...] to control and focus [...] meaningfulness into a more singular preferred meaning that performs the work of the dominant ideology." 46 To clarify, repetition of particular cinematic techniques (including camera angles, editing, casting and mise en scène) construct "codes" that translate into archetypes and expectations. Thus, Frears's fragmentation of Senay's body through the act of un-representing her hands deconstructs the female migrant body in a manner that has the potential to create an archetype so overly signified that the practice becomes a code (or "rule-governed system of signs" ${ }^{47}$ ).

The significance of fragmentation of the female body on screen is evaluated in Laura Mulvey's foundational text, "Visual Pleasures and Narrative Cinema," wherein she claims that the cinematic gaze (i.e. the camera angle) replicates the male gaze that objectifies women's bodies. With specific interest in the manner with which the cinematic gaze deconstructs the female body into fetishized parts (assumedly by means of close-up, camera pan, and American-shot), Mulvey suggests that the fragmentation of the female body eliminates the cinematic heroine's threat to the male phallus (both of her co-star and of the male audience). She claims that:

the male unconscious has two avenues of escape from ... castration anxiety: reoccupation with the re-enactment of the 
original trauma $[\ldots]$ counterbalanced by the devaluation, punishment or saving of the guilty object $[\ldots]$; or else complete disavowal of castration by the substitution of a fetish object or turning the represented figure itself into a fetish. ${ }^{48}$

The fetishized figure is the female body, and although Mulvey suggests that visual framing traditionally sexualizes the heroine (by means of a "close-up [...] of legs (Dietrich, for instance) or a face (Garbo)" ${ }^{\prime 9}$ ), I maintain that the essential motivation - to disempower the body through fragmentation - extends to correlate female migrants in film. For, intimidated by the enigmatic existence of the female refugee, the male cinema gaze creates either a monster or an object of desire out of her - therefore allowing itself justification of its defence mechanism - the unprotected objectification through filmic framing. Furthermore, the removal of visual representation of hands is significantly important in these films - as hands pose the greatest threat of castration to the male actor and viewer - although Senay makes her mouth equally dangerous.

However, I would like to propose an alternative to this feminist theorization - one that returns to Said's argument of exile and mourning. Recall that it is mourning, for Said, which motivates the actions of refugees, exiles, and diasporic people, as they are fractured from their original culture, history, and family. "Reflections on Exile" identifies the subject in relation to his or her previous ethnicity, nationality, and identity - as opposed to her present state of marginalization within her "host nation" typical of most refugee and migration analysis. ${ }^{50}$ In an earlier text, Said elaborates on the liminality of exiled experience - existing within a chasm formed between the past and present (national) identity. He writes that the exiled person is in a

state of never being fully adjusted, always feeling outside the chatty, familiar world inhabited by natives [...] Exile for the intellectual in this metaphysical sense is restlessness, movement, constantly being unsettled, and unsettling others. You cannot go back to some earlier and perhaps more stable condition of being at home; and, alas, you can never fully arrive, be at one in your new home or situation. ${ }^{51}$

Said's reiteration that exiles are "cut off" 52 from both present socialization and their past lives, including nation, family, and culture, illustrates a fragmentation of identity represented literally by Senay through the cinematic fragmentation of her literal body. In other words, the filmic deconstruction of the female migrant body potentially mimics the psychological fracture occurring between her and her original identity/nationality.
Proof of this claim lies in the economic symbolism that Senay's hands represent. As noted above, the female migrant labourer's hands are her primary source of survival as she financially provides for herself through manual labour. I would argue that the migrant's body represents her past identity - one that dances and sings to music, ${ }^{53}$ one that can sexually protect itself and is not objectified by the coercive demands of policing immigration officials. Comparatively, her hands embody the nature of their manual labour - her industrial slavery and sexual exploitation - that coincides with her marginalized status. By separating images of the labouring hands from the body, Frears's film illustrates the binary of Said's past versus present exile status. The fragmentation of Senay's migrant body implies the destabilized nature of her character - liminal between nationalities, ethnicities, and identities. For it is only when the subaltern rejects her status as an industrial slave-a slave of her status and her new country of residence - that her working hands are finally visualized. Recall how Senay's hands, when assisting Okwe with the surgery on the sleeping Señor Juan, are unmechanized, valued, and visible. Senay is liberated shortly after her working hands become visible - given a new identity that will release her from her migrant status and bodily distortion associated with manual labour in film. Therefore, once Senay's visualized body is repaired and represented in full she is able to overcome the limitations of her metaphoric refugee state (as a persecuted, violated, and abused figure who seeks freedom from the nation that politically allows these oppressions upon her). Although her newly constructed identity will only perpetuate Said's melancholia of liminality in New York (as she must repress her previous nationality entirely - therefore, failing to overcome her grief and disallowing proper mourning to occur), Senay is now granted subjectivity both from her liberation from repetitive manual labour and from the wholeness of her body.

In his text "The Mirror State," wherein he employs psychoanalysis to the process of subject-formation, Jacques Lacan notes that anxiety over "the fragmented body [... disjointed limbs" creates a phantasmic "fragilization" 54 that is evident as a symptom of hysteria. Fortunately, recognition of the self's reflection, the reassemblance of the visualization of the literal body, correlatively occurs with "the formation of the I" or the development of subjectivity. ${ }^{55}$ Likewise, Senay's construction of the "I" of her subjectivity parallels the moment of liberation when her body is reassembled on the screen. Furthermore, when Lacan suggests that that conscious-subconscious binary is developed during the process of subject formation, he implicitly relates linguistic development with the construction of the "I." In a previous essay entitled "The Instance of the Letter in the 
Unconscious or Reason since Freud," Lacan writes that "what the psychoanalytic experience discovers in the unconscious is the whole structure of language." 56 Implied by this statement is the interrelatedness of subjectivity and language (as both are formed out of repression). What becomes interesting, thus, is that Senay is able to vocalize her identity (albeit her "false" identity) for the first time in the film once she gains her illegitimate passport. Whereas the viewer never hears Senay use language to identify herself when she is the visually fragmented migrant, she is able to repeat her name convincingly after her subjectivity has been regained through the cinematic assemblage of her body. No longer does she have to rely on her eyes for expression or her hands for identity - as her voice is developed alongside her new-found subjectivity.

Of course, Senay's constructed identity is problematized by the mere fact that she must perform a culture, status, and name that do not belong to her. However, recalling the works of noted scholars, such as Rey Chow - whose muchcited notion of "coercive mimeticism" points to the constructed and performed nature of culture, ethnicity, and (implicitly) race - it is revealed that Senay's relegation to a new cultural identity is not one of necessary loss through assimilation/transformation. Instead, Frears concludes his film by acknowledging the inescapability of performing culture; he somehow optimistically guides the viewer to understand that Senay, with her family in New York, will maintain a cultural identity (possibly further graduating from the melancholia of exile to mourning), not as a superficial and essentialized performance, but rather as the substance and identity beneath her disguise.

Subjectivity, it is made evident, is the plight of migrants and refugees in the film (mimicking reality), as Senay works toward reconstituting herself in a manner not solely based on her body. The audience is left to believe (with some naive relief) that Senay's new identity allows her to experience ethnicity in New York without the specific fragmented objectification and excessive bodily emphasis that she has previously endured. After all, the image of the migrant implies so much more than the visual representation presented in cinema. Senay is a hybrid of the past and the present, seeking to gain her own identity by reassembling her body and shifting her archetypical recognition from corporeality to her voice.

\section{Notes}

1. Steven Frears directs Dirty Pretty Things (UK: Miramax, 2003). As the film nears its conclusion, Okwe makes an illegal trade with the black-market doctor. His response to the doctor's questioning encompasses the various "jobs" performed by the marginalized and dehumanized refugees throughout the film.
2. The term "refugee" is defined in the 1951 Refugee Convention and is often a politically loaded term that implies asylum for individuals from another geographic location who find themselves in circumstances where they are persecuted because of their race, class, political opinion, sexuality, etc. The characters in Dirty Pretty Things are, for the most part, illegal migrants. However, Okwe is a transmigrant who is forced to leave his country of origin, Nigeria, due to the unjust legal system that presumes his guilt for the murder of his wife. Despite the fact that his circumstances do not necessarily meet the legal definition of "refugee" - I contend that his circumstances in his country of origin are so threatening that he had to seek asylum in Britain. Furthermore, Okwe's situation is complicated by this unacknowledged status as a refugee - at least in terms of immigration policy. Thus, I refer to Okwe as a refugee not in the conventional, legal manner, but instead based on his desperation to leave Nigeria as a result of the dangerous and oppressive moral and legal systems.

3. "Awards for Dirty Pretty Things" in Internet Movie Database, <http://www.imdb.com/title/tt0301199/awards> (accessed December 6, 2005).

4. I use this terms "West" and "Western" ideologically rather than geographically, to include Britain, the United States, and Canada.

5. While there are several non-fiction journalistic or documentary accounts of refugees (including films that centre on contemporary issues such as Taran Davis's directed film, Afghan Stories (US: Seventh Art Releasing, 2002) and films that contextualize historical events, like director Mark Jonathan Harris's The Long Way Home (US: Seventh Art Releasing, 1997), there is a striking lack of fictional filmic narratives that articulate the hardships of refugee status. In 1948, director Lewis Milestone released Arch du Triumph, starring Ingrid Bergman (US: United Artists), and in 2003 Nigel Barker directed Asylum about a Christian minister who protects Iraqi refugees by hiding them in his church (UK: Committee Films, 2003).

6. Michael M. J. Fischer, "Starting Over: How, What, and for Whom Does One Write about Refugees? The Poetics and Politics of Refugee Film as Ethnographic Access in a Media Saturated World," <http://www.ssc.uwo.ca/anthropology/ farah/anthro507/Presentations/Anthropology507b-14\%5B 1\%5D.1.doc> (accessed December 6, 2005). Fischer argues that cinema is an ideal medium through which refugees and former refugees can speak out against the mainstream cultures of their new countries. Not only is the creative process therapeutic in Fischer's eyes, but the vocalization and visualization of refugee experiences enables the works to "intervene in the international public culture."

7. Terrence Wright, "Refugees on Screen" (RSC Working Paper no. 5, Refugee Study Centre, University of Oxford, 2000).

8. I hesitate to use the term "immigrant" due to the implications of assimilation and permanency that surround such vocabulary. Rather, I lean toward the definition provided by Nations Unbound, that notes that the "migrant" condition is one of temporality, national un-identification, and movement. As is 
demonstrated by that characters' constant repositioning in Dirty Pretty Things, the term "migrant" is far more fitting to their experiences. For more on the difference between migrancy, immigrancy, and transmigrancy, see Linda Green Basch, Nina Glick Schiller, and Cristina Szanton Blanc, $\mathrm{Na}$ tions Unbound (NY: Routledge, 1994).

9. Allen Feldman, "On Cultural Anaesthesia: From Desert Storm to Rodney King," American Ethnologist 21 (1994): 407, 404-18.

10. Julia Kristeva, Pouvoirs de l'horreur (Paris: Seuil, 1980).

11. Prem Kuma Rajaram, "Humanitarianism and Representations of the Refugee," Journal of Refugee Studies 15, no. 3 (2002): 248, 247-64.

12. Ibid., 251 [italics added].

13. Unlike Okwe, who is an illegal migrant, Senay has gained some political acknowledgement as a legal immigrant - still unable to work in Britain. Interestingly, Senay's legal status thrusts her into the same situation of hiding that Okwe finds himself in, as she is prohibited from working. While Okwe flees his past, Senay must flee her present, as immigration officials' surveillance follows her wherever she goes. Together, Okwe and Senay demonstrate the likenesses of the trials encountered by migrants to the West, regardless of their location on the continuum of immigration.

14. Throughout the film, Senay's protects her virginity as is dictated by her Muslim faith. Her loss of innocence is matched by her loss of faith ("My God does not speak to me anymore," she admits) - and the audience is to understand that losing her organs pales in comparison to this violation.

15. Sigmund Freud, "Mourning and Melancholia," Standard Edition of the Complete Psychological Works, vol. 14, trans. James Strachey, 243, 243-58.

16. Tammy Clewell, "Mourning beyond Melancholia: Freud's Psychoanalysis of Loss," Journal of the American Psychoanalytic Association 52, no. 1 (2004): 44, 43-67.

17. Although being an "exile" and a "refugee" are distinct subjectivities, here I connect them on the grounds that they both feel political and/or social pressure to leave their countries of origin and, therefore, must relocate in an unfamiliar, and at times hostile, environment.

18. Edward Said, "Reflections on Exile," in Reflections on Exile and Other Essays (Cambridge, MA: Harvard University Press, 2002), 177, 173-86.

19. Bruce Robbins, "Homelessness and Worldliness," Diacritics: A Review of Contemporary Criticism 13, no. 3 (1983): 69, 69-73.

20. Ibid., 69.

21. Oxford English Dictionary Online (accessed December 19, 2005).

22. Freud, "Mourning and Melancholia," 244-45.

23. Sigmund Freud, "The Uncanny," in Literary Theory: An Anthology, $2^{\text {nd }}$ ed., ed. Julie Rivkin and Michael Ryan (Malden: Blackwell, 2004), 424, 418-30.

24. Ibid., 424 .
25. William Shakespeare, Sonnet 132, lines 1-3, 9, in The Norton Shakespeare, ed. Stephen Greenblatt (New York: W.W. Norton, 1997).

26. Raphael, The Entombment, Galleria Borghese, Rome.

27. Gayatri T. Spivak, "Can the Subaltern Speak?" in The Post-Colonial Studies Reader, ed. B. Ashcroft, G. Griffiths, and H. Tiffin (New York: Routledge, 1995), 24-28.

28. Rajaram, 252.

29. Again, despite the fact that Senay is a legal migrant in England, she mirrors the refugee experience when she is forced to seek asylum from the sexually exploitative, violating, and dehumanizing social system of immigrant lifestyle. She is hunted by immigration officers representing the nation and must buy her freedom to the United States as a means of fleeing her current state. Interestingly, Senay is transformed into a "refugee" from not her country of origin, but the country of her migration.

30. Ibid., 251.

31. Despite the fact that Senay is a legal migrant, she is pursued and limited in a manner that suggests wrongness on her part. Similar to the effect of the panopticon, the surveillance by the immigration officials and the sexual predators leaves Senay marginalized by the threat of discipline.

32. Kerry Demusz, Listening to the Displaced: Action Research in the Conflict Zones of Sri Lanka (Oxford: Oxfam, 1995), 7.

33. Rajaram, 251.

34. Ibid., 251.

35. Which is different from being a model minority, as an Oriental is never assimilated or viewed in any way as Self instead of Other.

36. Liisa H. Malkki, "Refugees and Exile: From 'Refugee Studies' to the Natural Order of Things," Annual Review of Anthropology 24 (1995): 496, 495-525.

37. Rey Chow, "Postmodern Automatons," in Feminists Theorize the Political, ed. Judith Butler and Joan W. Scott (New York: Routledge, 1992), 101-17.

38. Ibid., 5, citing J. Smith, Melodrama (London: Methuen, 1973).

39. Judith Butler, Gender Trouble (New York: Routledge, 1999), 185.

40. See para. 11 in Beth Harris's "Slaves of the Needle: The Seamstress in the 1840s," on The Victorian Web, <http://www.victorianweb.org/gender/ugoretz1.html $>$ (accessed December 6, 2005).

41. Annemarie Kemeny, "The Female Machine in the Postmodern Circuit," in Liminal Postmodernisms: The Postmodern, the (Post-)Colonial, and the (Post-)Feminist, ed. Theo D'haen and Hans Bertens (Amsterdam: Atlanta, 1994), 261, 255-73.

42. Ibid., 261.

43. For more on DuBois, consider "W.E.B. DuBois and DoubleConsciousness," California State University, 2000, $<$ http://www.csudh.edu/dearhabermas/dubois.htm> (accessed December 6, 2005).

44. John Fiske, “Television Culture," in Literary Theory: An Anthology, $2^{\text {nd }}$ ed., ed. Julie Rivkin and Michael Ryan (Malden: Blackwell, 2004), 1277, 1274-84. 
45. Ibid., 1275.

46. Ibid., 1274.

47. Ibid., 1275.

48. Laura Mulvey, "Visual Pleasures and Narrative Cinema," Screen 16, no. 3 (1975): 10, 6-18.

49. Ibid., 12.

50. For instance, see Mireille Rosello, Postcolonial Hospitality: The Immigrant as Guest (Stanford: Stanford University Press, 2001).

51. Edward Said, Representations of the Intellectual: The 1993 Reith Lectures (New York: Pantheon Books, 1994), 39.

52. Said, "Reflections," 177.

53. In one scene, Senay is pictured recalling her ethnic past, dancing fanatically to Turkish music in her apartment. This unsettling scene, wherein she is wide-eyed and moves chaoti- cally, suggests that her country and culture of origin are both the cause and (unknowable) cure for her pain.

54. Jacques Lacan, "The Mirror Stage as Formative of the Function of the I as Revealed in Psychoanalytic Experience," in Literary Theory: An Anthology, ed. Julie Rivkin and Michael Ryan (Malden: Blackwell, 2004), 444, 447-61.

55. Ibid., 444.

56. Ibid., 447.

Jenny Wills is currently pursuing her Ph.D. in English Literature at Wilfrid Laurier University in Waterloo, Ontario. Her primary research interests include Asian adoption fiction and film, fashion in literature, and the Victorian novel. 